\title{
Factors that Affect Female Trainees' Academic Achievement in Teacher Training Colleges of Tigrai, Ethiopia
}

\author{
Teklu Gebremedhin \\ MA in Gender and Development Studies, College of Social Science and Humanities, Raya University, Po Box \\ 92, Tigrai, Ethiopia \\ Nega Gebreegzi \\ MA in Gender and Development Studies, Abbi-Addi College of Teachers' Education and Educational \\ Leadership, Tigrai, Ethiopia
}

\begin{abstract}
The study was conducted in teacher education colleges of Tigrai with a prime objective of assessing factors that affect the academic achievement of female trainees. Quantitative and qualitative data was collected from participants using primary and secondary data sources. Questionnaire, key informant interview and document analysis were used as data collection instruments. Primary data was collected from female trainees, female instructors, management bodies, student council and gender office coordinators. In this study simple random sampling was employed. Using Yemane's sample size determination formula 263 female trainees were participated in the study. Descriptive statistics was used as data analysis technique in this study. The finding revealed that female trainees' register low academic achievement as compare to male trainees due to multifaceted factors such as institutional, instructors', parents' and female trainees' related factors. Institutional factors include lack of guidance and counseling service, less attractive rewards given for better achievers, lack of proper reading place, lack of health care services in the campus and lack of dormitory service. Moreover, lack of role model female instructors and instructors' effective advisory role are instructors' related factors that affect female trainees' academic success. In addition female trainees' academic success hinders by their self-motivation, low selfconfidence, low studying effort, poor academic performance in high school, peer pressure, low reading experience in library and low attitude for education. Parents' socio-economic background and financial support were also parents' related factors. Hence, the researchers recommends colleges, Tigrai education bureau, academic staff and other governmental and non- governmental organizations should give due attention to narrow the gap and improve the academic achievement of female trainees and promote their competency.
\end{abstract}

Keywords: Academic achievement, Female trainees, education, GPA, College, Tigrai

DOI: $10.7176 / \mathrm{JEP} / 11-1-01$

Publication date: January $31^{\text {st }} 2020$

\section{Introduction}

Education is a womb of all professions and professionals. It is the harmonious development of mental, moral, and social affairs of individuals' life (Tiruneh and Petros, 2014). Participation of females in socio-economic development programs also depends on their educational backgrounds and their professionalism (Komba and Nkumbi, 2008). One of the main goal of education is to bring up citizens endowed with human outlook, country wide responsibility and democratic values, having developed the necessary productive, creative and appreciative capacity in order to participate fruitfully in the development and utilization of resources and the environment at large (O-saki, 2003).

Ethiopia has had development policy directions which are entirely dedicated to ensure equitable and inclusive socio-economic development to reduce poverty at all levels. To this end human development has been placed at the center of any development agenda of the country. As a result, all of the policy directions such as the Sustainable Development and Poverty Reduction Program (SDPRP), the Plan for Accelerated and Sustained Development to End Poverty (PASDEP), Education Sector Development Program IV and V and the Growth and Transformation Plan (GTP) envisaged education as one of the most potential instrument to realize Ethiopia's development vision, where there is a critical need for middle and higher level skilled human power.

Despite the fact that female students got high due attention, $t$ he number of female students who graduate from higher institutions are still less as compared with their male counter parts due to different factors. Thus, this study focuses on assessing factors affecting female students' academic achievement at Teachers' education colleges of Tigrai. Hence, the following are the main motivating factors to deal with this study. First, as far as the researchers concerned less has been made on this issue. The other major reason to deal with this study was women's vulnerability to gender discrimination is still the persistent legacy. The specific objectives of the study are the following.

$>$ Investigate the academic performance of female trainees;

$>$ Analyze factors that affect academic achievement of female trainees; 


\section{Methodology}

The study was conducted in government teacher education and educational leadership colleges of Tigrai regional state, Ethiopia. In this study to clearly explore the academic status of female trainees' and factors that affect their academic achievement descriptive survey design was applied. To explain numeric explanation of the data collected from female trainees' quantitative approach was employed. To describe non-numeric explanation of ideas and perceptions qualitative approach was used. Both primary and secondary data source was utilized in the study. Besides, questionnaire, key informant interview and document analysis were used as data collection instruments.

Simple random sampling was employed to select sample respondents. Using Yamane's (1967) sample size determination formula 263 female trainees were participated in the study and completed the questionnaire. In addition, non-probability (purposive) sampling method was adopted to select samples from female instructors, management bodies, student councils and gender officers for interview purpose. Hence, 12 participants were interviewed. SPSS version 20 was used as data analysis tool in the study. Finally qualitative and quantitative data analysis techniques were used. Data generated through questionnaire was analyzed using descriptive statistics such as frequency and percentages to characterize the academic performance of female trainees and factors that affect their academic competence quantitatively.

\section{Result and discussion}

\section{Academic achievement of female trainees}

The academic status of female trainees in both teacher education colleges was assessed. To see full image about the academic achievement of female trainees' we take the academic result of all trainees and analyzed in the following manner. The next two consecutive tables clearly indicate the actual academic status of trainees in both teacher education colleges. Table 1 and 2 below describe the academic status of Adwa and Abbi-Addi College trainees respectively.

Table 1: Academic status of Adwa college trainees (2014/15 and 2015/16 entry)

\begin{tabular}{|c|c|c|c|c|c|c|c|c|}
\hline \multirow{3}{*}{$\begin{array}{c}\text { Participants GPA and } \\
\text { its category }\end{array}$} & \multicolumn{4}{|c|}{ Adwa College $2^{\text {nd }}$ year trainees } & \multicolumn{4}{|c|}{ Adwa College $3^{\text {rd }}$ year trainees } \\
\hline & \multicolumn{2}{|c|}{ Male } & \multicolumn{2}{|c|}{ Female } & \multicolumn{2}{|c|}{ Male } & \multicolumn{2}{|c|}{ Female } \\
\hline & Freq. & Percent & Freq. & Percent & Freq. & Percent & Freq. & Percent \\
\hline Very Great Distinction & 59 & 4.27 & 9 & .65 & 45 & 3.09 & 13 & .89 \\
\hline Great Distinction & 67 & 5 & 34 & 2.46 & 92 & 6.32 & 42 & 2.9 \\
\hline Distinction & 95 & 6.9 & 60 & 4.35 & 142 & 9.76 & 122 & 8.39 \\
\hline Pass & 402 & 29.15 & 567 & 41.11 & 454 & 31.22 & 490 & 33.7 \\
\hline Warning & 20 & 1.45 & 53 & 3.84 & 7 & .48 & 22 & 1.5 \\
\hline Probation & 5 & .36 & 8 & .58 & 2 & .14 & 2 & .14 \\
\hline Dropout & - & & - & & 4 & .27 & 17 & 1.17 \\
\hline Total & 648 & 47 & 731 & 53 & 746 & 51.3 & 708 & 48.7 \\
\hline
\end{tabular}

Source: Adwa college registrar office (2017)

Table 2: Academic status of Abbi-Addi College trainees (2014/15 and 2015/16 entry)

\begin{tabular}{|c|c|c|c|c|c|c|c|c|}
\hline \multirow{3}{*}{$\begin{array}{l}\text { Participants GPA and } \\
\text { its category }\end{array}$} & \multicolumn{4}{|c|}{ Abbi-Addi College $2^{\text {nd }}$ year trainees } & \multicolumn{4}{|c|}{ Abbi-Addi College $3^{\text {rd }}$ year trainees } \\
\hline & \multicolumn{2}{|c|}{ Male } & \multicolumn{2}{|c|}{ Female } & \multicolumn{2}{|c|}{ Male } & \multicolumn{2}{|c|}{ Female } \\
\hline & Freq. & Percent & Freq. & Percent & Freq. & Percent & Freq. & Percent \\
\hline $\begin{array}{ll}\text { Very } & \text { Great } \\
\text { Distinction } & \end{array}$ & 57 & 4.84 & 21 & 1.78 & 116 & 8.3 & 56 & 3.99 \\
\hline Great Distinction & 133 & 11.3 & 57 & 4.84 & 203 & 14.48 & 82 & 5.84 \\
\hline Distinction & 148 & 12.57 & 90 & 7.65 & 181 & 12.91 & 132 & 9.41 \\
\hline Pass & 269 & 22.85 & 369 & 31.35 & 201 & 14.34 & 427 & 30.45 \\
\hline Warning & 4 & .34 & 27 & 2.3 & - & - & 3 & .21 \\
\hline Probation & - & - & 2 & .17 & 1 & - & - & - \\
\hline Dropout & - & - & - & - & - & - & - & - \\
\hline Total & 611 & 51.9 & 566 & 48.1 & 702 & 50.1 & 700 & 49.9 \\
\hline
\end{tabular}

Source: Abbi-Addi college registrar office (2017)

The above tables clearly indicate that female trainees' are generally concentrated highly in the middle and lower academic status. Thus, the analysis indicates that female trainees are less effective to register higher academic status. This is inconsistent with their equal opportunity they enjoy and substantiated by the strategy of affirmative action which enables female trainees to join teacher education colleges' proportionally with males irrespective of the result they score during entrance exam. 


\section{Factors that affect female trainees' academic achievement}

Analysis of data showed that there are different factors that affect the academic achievement of female trainees at teacher education and educational leadership colleges. This are categorized in to four major categories such as, institutional related, instructors' related, female trainees related and parents related factors.

\section{Institutional related factors}

Participants were asked to give their overall agreement about college related factors such as affirmative action strategies, college rules \& regulations, awareness and sensitivity of staff about gender issue, guidance and counseling service, rewards given for better achievers, availability of proper reading place, availability of health care service, availability of pedagogical center, access to ICT and internet service, availability of dormitory service, department placement of trainees and trainees' club participation. The analysis indicates that majority of participants agree about the effect of these factors on female trainees' academic achievement in teacher education colleges (table 3 below).

Table 3: Institutional factors on the academic achievement of female trainees

\begin{tabular}{|c|c|c|c|c|c|c|c|c|c|c|}
\hline \multirow{3}{*}{ Institutional factors } & \multicolumn{10}{|c|}{ Level of agreement } \\
\hline & \multicolumn{2}{|c|}{ Very low } & \multicolumn{2}{|c|}{ Low } & \multicolumn{2}{|c|}{ Medium } & \multicolumn{2}{|c|}{ High } & \multicolumn{2}{|c|}{ Very high } \\
\hline & Count & $\mathrm{N} \%$ & Count & $\mathrm{N} \%$ & Count & $\mathrm{N} \%$ & Count & $\mathrm{N} \%$ & Count & $\mathrm{N} \%$ \\
\hline $\begin{array}{l}\text { Affirmative action } \\
\text { strategies }\end{array}$ & 41 & 14.4 & 67 & 23.6 & 99 & 34.9 & 43 & 15.1 & 33 & 11.6 \\
\hline $\begin{array}{l}\text { College rules } \quad \& \\
\text { regulations }\end{array}$ & 64 & 22.5 & 90 & 31.7 & 76 & 26.8 & 27 & 9.5 & 27 & 9.5 \\
\hline $\begin{array}{l}\text { Awareness and } \\
\text { sensitivity of staff }\end{array}$ & 54 & 19.0 & 71 & 25.0 & 77 & 27.1 & 35 & 12.3 & 47 & 16.5 \\
\hline $\begin{array}{l}\text { Guidance and } \\
\text { counseling service }\end{array}$ & 41 & 14.4 & 49 & 17.3 & 78 & 27.5 & 57 & 20.1 & 58 & 20.4 \\
\hline $\begin{array}{l}\text { Rewards given for } \\
\text { better achievers }\end{array}$ & 28 & 9.9 & 37 & 13.0 & 69 & 24.3 & 71 & 25.0 & 78 & 27.5 \\
\hline $\begin{array}{l}\text { Lack of proper reading } \\
\text { place }\end{array}$ & 31 & 10.9 & 36 & 12.7 & 72 & 25.4 & 68 & 23.9 & 77 & 27.1 \\
\hline $\begin{array}{l}\text { Availability of health } \\
\text { care service }\end{array}$ & 43 & 15.1 & 50 & 17.6 & 73 & 25.7 & 57 & 20.1 & 60 & 21.1 \\
\hline $\begin{array}{ll}\begin{array}{l}\text { Availability } \\
\text { pedagogical center }\end{array} & \text { of } \\
\end{array}$ & 28 & 9.9 & 41 & 14.4 & 99 & 34.9 & 64 & 22.5 & 51 & 18.0 \\
\hline $\begin{array}{l}\text { Access to ICT and } \\
\text { internet service }\end{array}$ & 37 & 13.0 & 53 & 18.7 & 89 & 31.3 & 60 & 21.1 & 43 & 15.1 \\
\hline $\begin{array}{l}\text { Lack of dormitory } \\
\text { service }\end{array}$ & 50 & 17.6 & 35 & 12.3 & 66 & 23.2 & 64 & 22.5 & 68 & 23.9 \\
\hline $\begin{array}{l}\text { Department } \\
\text { placement of trainees }\end{array}$ & 40 & 14.1 & 50 & 17.6 & 58 & 20.4 & 39 & 13.7 & 96 & 33.8 \\
\hline $\begin{array}{ll}\text { Trainees' } & \text { club } \\
\text { participation } & \\
\end{array}$ & 32 & 11.3 & 60 & 21.1 & 97 & 34.2 & 49 & 17.3 & 45 & 15.8 \\
\hline
\end{tabular}

The main institutional factors that affect female trainees' academic achievement are identified and analyzed. The following are the most important institutional factors as per to the finding in both colleges.

Department placement of trainees' plays a key role in their future life adjustment and their academic success in a given field of study. If trainees are placed based on their interest in the department, they can be successful in their academic endeavors (Tiruneh and Petros, 2014). In this study department placement of trainees was a major factor that hinder the academic performance of female trainees. Trainees are placed in to different departments based of their academic performance. As a result if their first choice is occupied by others, they are forced to place in another department which is not their priority. This in turn affects their interest and competence in the academia.

In addition participants stated that rewards given for better achievers is not encouraged and motivated for others so as to score better academic result. According to the finding above, this is the second most important factor that affects female trainees' academic performance. As per to the information collected from key informants most of the time better achievers are rewarded stationary materials which they claimed below the required standard at college level. Guidance and counseling service plays crucial role to motivate and solve their social and psychological problems of female trainees especially in teacher education colleges. Despite of this fact the analysis indicates that lack of guidance and counseling service is the next most important factor that affects academic achievement of female trainees.

Lack of proper reading place which is separated and prepared only for female trainees is another factor that 
affect for female trainees especially in the case of Adwa College of teacher education. Moreover, lack of health care services in the campus, lack of pedagogical center, access to ICT and internet service and lack of dormitory service were institutional factors identified in the analysis.

Most of the above identified factors were also mentioned by key informants during the interview schedule. For instance, weak or absence of active gender sensitive guidance and counseling service, less attractive rewards given for female better achievers, lack of separate reading room for females in the library particularly in Adwa College were the major challenges for female trainees. Lack of separate reading room for female trainees in the library may expose female trainees for different biological and social inconveniences.

\section{Instructors related factors}

Participants stated their agreement about instructors' related factors such as instructors' commitment to support female trainees, clarity of instructors' presentation in recognizing female trainees' learning pace, existence of role model female instructors' in the college, male instructors' sexual harassment over female trainees and instructors' effective advisory role on the academic achievement of female trainees at teacher education and educational leadership colleges (Table 4 below).

Table 4: Instructors related factors on the academic achievement of female trainees

\begin{tabular}{|c|c|c|c|c|c|c|c|c|c|c|}
\hline \multirow{3}{*}{$\begin{array}{c}\text { Instructors related } \\
\text { factors }\end{array}$} & \multicolumn{10}{|c|}{ Level of agreement } \\
\hline & \multicolumn{2}{|c|}{ Very low } & \multicolumn{2}{|c|}{ Low } & \multicolumn{2}{|c|}{ Medium } & \multicolumn{2}{|c|}{ High } & \multicolumn{2}{|c|}{ Very high } \\
\hline & Count & N\% & Count & $\mathbf{N} \%$ & Count & $\mathbf{N} \%$ & Count & N\% & Count & N\% \\
\hline $\begin{array}{l}\text { Instructors' } \\
\text { experience in } \\
\text { solving female } \\
\text { trainees' academic } \\
\text { challenges }\end{array}$ & 34 & 12.9 & 51 & 19.4 & 100 & 36 & 35 & 13.3 & 43 & 16.3 \\
\hline $\begin{array}{l}\text { Instructors' } \\
\text { commitment to } \\
\text { support female } \\
\text { trainees }\end{array}$ & 34 & 12.9 & 60 & 22.8 & 72 & 27.4 & 59 & 22.1 & 39 & 14.8 \\
\hline $\begin{array}{l}\text { Clarity of teachers } \\
\text { presentation in } \\
\text { recognizing female } \\
\text { trainees' learning } \\
\text { pace }\end{array}$ & 34 & 12.9 & 48 & 18.3 & 84 & 31.9 & 58 & 22.1 & 39 & 14.8 \\
\hline $\begin{array}{l}\text { Lack of role model } \\
\text { female instructors' } \\
\text { in the college }\end{array}$ & 42 & 16 & 56 & 21.3 & 64 & 24.3 & 56 & 21.3 & 45 & 17.1 \\
\hline $\begin{array}{l}\text { Lack of qualified } \\
\text { and experienced } \\
\text { teachers }\end{array}$ & 68 & 25.9 & 76 & 28.9 & 65 & 24.7 & 33 & 12.5 & 21 & 8 \\
\hline $\begin{array}{lc}\text { Male instructors' } \\
\text { sexual harassment } \\
\text { over female trainees }\end{array}$ & 79 & 30 & 65 & 24.7 & 59 & 22.4 & 21 & 8 & 39 & 14.8 \\
\hline $\begin{array}{l}\text { Instructors' effective } \\
\text { and consistency } \\
\text { advisory role }\end{array}$ & 46 & 17.5 & 30 & 11.4 & 80 & 30.4 & 62 & 23.6 & 45 & 17.1 \\
\hline
\end{tabular}

Instructors' have a central role and plays significant contribution in the teaching and learning process. Instructors' have positive role to create conducive learning environment. Despite of this fact the analysis revealed that the following instructors' related factors affect the academic achievement of female trainees such as instructors' commitment to support female trainees, clarity of instructors' presentation in recognizing female trainees' learning pace, lack of role model female instructors' in the colleges and instructors effective advisory role. The existence of role model female instructors' in the colleges can contribute crucial value to encourage female trainees in their academic endeavor. Despite of this fact, the finding indicates there is lack of good role models. In addition significant number of participants stated that male instructors' sexual harassment over female trainees also affects the academic achievement of female trainees.

Female trainees related factors

In this study participants were asked to state their agreement about the effect of female trainees related factors on their academic achievement. The following table illustrates female trainees' related factors in their academic 
performance.

Table 5: Female trainees' related factors on their academic achievement

\begin{tabular}{|c|c|c|c|c|c|c|c|c|c|c|}
\hline \multirow{3}{*}{$\begin{array}{l}\text { Female trainees } \\
\text { related factors }\end{array}$} & \multicolumn{10}{|c|}{ Level of agreement } \\
\hline & \multicolumn{2}{|c|}{ Very low } & \multicolumn{2}{|c|}{ Low } & \multicolumn{2}{|c|}{ Medium } & \multicolumn{2}{|c|}{ High } & \multicolumn{2}{|c|}{ Very high } \\
\hline & Count & $\mathbf{N} \%$ & Count & $\mathbf{N \%}$ & Count & $\mathbf{N \%}$ & Count & $\mathbf{N} \%$ & Count & $\mathrm{N} \%$ \\
\hline $\begin{array}{l}\text { Female trainees' } \\
\text { self motivation }\end{array}$ & 41 & 15.6 & 56 & 21.3 & 86 & 32.7 & 49 & 19.6 & 31 & 11.8 \\
\hline $\begin{array}{l}\text { Abnormal relation } \\
\text { with teachers' }\end{array}$ & 60 & 22.8 & 89 & 33.8 & 86 & 32.7 & 17 & 6.5 & 11 & 4.2 \\
\hline $\begin{array}{l}\text { Abnormal relation } \\
\text { with male trainees }\end{array}$ & 43 & 16.3 & 77 & 29.3 & 84 & 31.9 & 34 & 12.9 & 25 & 9.5 \\
\hline $\begin{array}{l}\text { Well planned } \\
\text { learning process }\end{array}$ & 41 & 15.6 & 17 & 6.5 & 81 & 30.8 & 82 & 31.2 & 42 & 16 \\
\hline $\begin{array}{l}\text { Self confidence of } \\
\text { female trainees' }\end{array}$ & 31 & 11.8 & 27 & 10,3 & 88 & 33.5 & 80 & 30.4 & 37 & 14.1 \\
\hline $\begin{array}{l}\text { Studying effort of } \\
\text { female trainees' }\end{array}$ & 37 & 14.1 & 39 & 14.8 & 69 & 26.2 & 77 & 29.3 & 41 & 15.6 \\
\hline $\begin{array}{ll}\text { Peer } & \text { pressure } \\
\text { problems }\end{array}$ & 40 & 15.2 & 72 & 27.4 & 87 & 33.1 & 39 & 14.8 & 25 & 9.5 \\
\hline $\begin{array}{l}\text { Limited experience } \\
\text { reading in library }\end{array}$ & 35 & 13.3 & 49 & 18.6 & 95 & 36.1 & 48 & 18 & 36 & 14 \\
\hline $\begin{array}{l}\text { Low attitude for } \\
\text { education }\end{array}$ & 70 & 26.6 & 72 & 27.4 & 79 & 30 & 26 & 9.9 & 16 & 6.1 \\
\hline $\begin{array}{l}\text { Repeated late and } \\
\text { absent from class }\end{array}$ & 71 & 27 & 77 & 29.3 & 84 & 31.9 & 16 & 6.1 & 15 & 5.7 \\
\hline $\begin{array}{l}\text { Shyness to } \\
\text { participate in class }\end{array}$ & 42 & 16 & 57 & 21.7 & 95 & 36.1 & 41 & 15.6 & 28 & 10.6 \\
\hline $\begin{array}{l}\text { The influence of } \\
\text { tension }\end{array}$ & 29 & 11 & 75 & 28.5 & 94 & 35.7 & 39 & 14.8 & 26 & 9.9 \\
\hline $\begin{array}{l}\text { Poor performance in } \\
\text { high school }\end{array}$ & 40 & 15.2 & 52 & 19.8 & 60 & 22.8 & 37 & 14.1 & 74 & 28.1 \\
\hline $\begin{array}{ll}\text { Difficulty } & \text { of } \\
\text { education } & \end{array}$ & 46 & 17.5 & 58 & 22.1 & 85 & 32.3 & 31 & 11.8 & 43 & 16.3 \\
\hline
\end{tabular}

Education needs an intrinsic motivation to be more effective. As per to the finding of this study female trainees' self motivation affects their academic performance. This in turn also hinders their self confidence which is another problem. In addition female trainees' lacks well planned learning, exert low studying effort and had poor academic performance in high school. All these affect their academic performance during their college education. Besides significant number of participants state their agreement that peer pressure, limited experience reading in library, low attitude for education, shyness to participate in class, the influence of tension and difficulty of education affects their academic achievement. This indicates that academic competence of female trainees is also affected by the moral strength and psychological makeup of themselves.

\section{Parents related factors}

The questionnaire also addresses the following issues such as socio-economic background of parents, attitude of parents on female education, parents control over female trainees and parents' financial support to analyze the effect of parent related factors on the academic achievement of female trainees in teacher education colleges. In this regard the analysis revealed that socio-economic background of parents and parents' financial support affects the academic achievement of female trainees (Table 6). 
Table 6: Parents related factors on the academic achievement of female trainees

\begin{tabular}{|l|c|c|c|c|c|c|c|c|c|c|}
\hline \multirow{2}{*}{$\begin{array}{l}\text { Parent related } \\
\text { factors }\end{array}$} & \multicolumn{10}{|c|}{ Level of agreement } \\
\cline { 2 - 13 } & \multicolumn{2}{|c|}{ Very low } & \multicolumn{2}{|c|}{ Low } & \multicolumn{2}{c|}{ Medium } & \multicolumn{2}{c|}{ High } & \multicolumn{2}{c|}{ Very high } \\
\hline $\begin{array}{l}\text { Socio-economic } \\
\text { status }\end{array}$ & 45 & 17.1 & 28 & 10.6 & 98 & 37.3 & 49 & 18.6 & 43 & 16.3 \\
\hline $\begin{array}{l}\text { Attitude of parents } \\
\text { on female education }\end{array}$ & 75 & 28.5 & 75 & 28.5 & 50 & 19 & 42 & 16 & 21 & 8 \\
\hline $\begin{array}{l}\text { Parents educational } \\
\text { level }\end{array}$ & 81 & 30.8 & 30 & 11.4 & 41 & 15.6 & 75 & 28.5 & 36 & 13.7 \\
\hline $\begin{array}{l}\text { Parents financial } \\
\text { support }\end{array}$ & 32 & 12.2 & 21 & 8 & 71 & 27 & 75 & 28.5 & 64 & 24.3 \\
\hline
\end{tabular}

As it indicates in the above table, participants agree that socio-economic status of parents and parents' financial support affects the academic achievement of female trainees in teacher education colleges. Both factors are interrelated each other. If socio-economic status of parents is low, their financial support becomes also low and vice versa. Most trainees' families are rural dwellers which depend mostly on traditional agricultural activities. Thus, due to those and other reasons parents' role to support their daughters is restricted. This in turn affects the academic achievement of female trainees in colleges.

\section{CONCLUSION}

The purpose of this study was to assess factors affecting the academic achievement of female trainees at teacher education and educational leadership colleges of Tigrai. In terms of academic success, document analysis result indicates female trainees are concentrated at the middle and lower academic status. To this end, female trainees' encounter multifaceted challenges that affect their academic achievement.

The study has tried to identify and analyze institutional related, instructors related, female trainees related and parents related factors that affect female trainees' academic achievement. Institutional related factors such as department placement challenges, lack of guidance and counseling service, less attractive rewards given for better achievers, lack of proper reading place, lack of health care services in the campus, lack of pedagogical center, access to ICT and internet service and lack of dormitory service were identified as the most important challenges that affects the academic achievement of female trainees in teacher education colleges.

Instructors related factors that affect female trainees' academic achievement include low commitment of instructors' to support female trainees, lack of role model female instructors' in the colleges and instructors effective advisory role. Moreover, the academic achievement of female trainees was affected by their self motivation, self confidence, planned learning habit, studying effort, poor academic performance in high school, peer pressure, limited experience reading in library, low attitude for education, shyness to participate in class, the influence of tension and difficulty of education. Academic achievement of female trainees' was also face parents related problems such as socio-economic status of parents and parents' financial support.

\section{Recommendations}

Based on the results and conclusions drawn, to alleviate factors that affect female trainees' academic achievement the following measures should be undertaken:

$>$ To motivate high achievers and other female trainees' rewards given at college level should be more attractive and advanced like scholarship opportunities for gold medal winners.

$>$ Guidance and counseling service should be given due attention by the college and Tigrai education bureau to minimize female trainees socio-cultural and psychological challenges and promote their academic success.

$>$ Colleges in collaboration with non-governmental organizations that activate on gender issues should conduct gender sensitive training for academic staff to increase their awareness about female trainees' special needs and interests.

$>$ Training which targets to enhance female trainee's self-motivation and self-confidence should be undertaken by gender coordinator office of both colleges in collaboration with governmental and nongovernmental organizations.

\section{REFERENCES}

Federal ministry of education (2015): Education Sector Development Program V (ESDP V), Addis-Ababa; Ethiopia

Komba L., Willy and Emmanuel Nkumbi(2008). Teachers professional development in Tanzania: Perceptions and Practices. Journal of International Cooperation in Education, Vol.11 No.3, 67-83

Ministry of education (2010): Education Sector Development Program IV (ESDP IV), Addis-Ababa; Ethiopia 
MOFED (2006): A Plan for Accelerated and Sustained Development to End Poverty (PASDEP), Addis-Ababa, Ethiopia

MOFED (2002): Ethiopia: Sustainable Development and Poverty Reduction Program, Addis- Ababa, Ethiopia

MOFED (2010): Federal Democratic Republic of Ethiopia, Growth and Transformation Plan (2010/11-2014/15), Addis-Ababa, Ethiopia

National Planning Commission (2016): Federal Democratic Republic of Ethiopia, Growth and Transformation Plan II (GTP II) (2015/16-2019/20), Addis-Ababa, Ethiopia

O-saki, K.M. (2003) National Capacity Building of Lead Teacher Training Institutions, UNESCO

Tiruneh, W. A., and Petros, P., (2014) Factors affecting female students' academic performance at higher education: The case of Bahir Dar University, Ethiopia, African Educational Research Journal Vol. 2(4), pp. $161-166$,

Yamane, T (1967). Statistics: An Introductory Analysis, $2^{\text {nd }}$ Ed., New York: Harper and Row. 